\title{
A model of antecedents strengthening organizational commitment
}

\author{
Dan Thanh Ly $y^{\mathrm{a}, \mathrm{b}, \mathrm{c}}$, Quang Thong Bui ${ }^{\mathrm{a}, \mathrm{b}}$, Van Chon Le ${ }^{\mathrm{a}, \mathrm{b}}$ and Nhu Ty Nguyen ${ }^{\mathrm{a}, \mathrm{b}^{*}}$
}

${ }^{a}$ School of Business, International University (IU), Vietnam

${ }^{b}$ Vietnam National University, HCM City, Vietnam

${ }^{c}$ Ho Chi Minh City University of Economics and Finance (UEF), Vietnam

\section{H R O N I C L E}

\section{Article history:}

Received: October 14, 2020

Received in revised format:

November 112020

Accepted: November 11, 2020

Available online:

November 11, 2020

Keywords:

Organizational commitment

Intrinsic motivation

Extrinsic motivation

Employee voice

Organizational identification

Perceived organizational commit-

ment

\section{A B S T R A C T}

Due mainly to the importance of organizational commitment for both employees and employers, it has been the subject attracting researchers over the last few decades. Therefore, the paper aims to build a model of antecedents strengthening organizational commitment. First, the paper reviews six main concepts including organizational commitment, intrinsic motivation, extrinsic motivation, employee voice, organizational identification and perceived organizational support. Next, Fivepoint Likert scale is used to measure those factors with two hundred and forty-nine fulltime Vietnamese employees who are working at 34 Vietnamese organizations from a variety of sectors such as tax, banking, health service, airlines, education and business. Finally, quantitative research is obtained by using EFA, CFA analysis and structural equation modeling. The findings show that three prominent factors positively affecting organizational commitment are intrinsic motivation, extrinsic motivation and organizational identification.

C) 2021 by the authors; licensee Growing Science, Canada

\section{Introduction}

The concept of organizational commitment has received increased attention from scholars and practitioners over the world. They have researched and conducted several social experiments to increase employee commitment to organizations (Moon, 2000; Steers, 1977). Employees are considered as organization's assets; therefore, they play the central role for several reasons. Buchanan (1974) and Wall (1980) confirm that employees feel tightly closed to goals and values of the organization toward organizational commitment. Previous researches also reveal that high performance is surely fulfilled by highly committed employees than less committed ones (Mowday, Steers, \& Porter, 1978; Steers, 1977). Put it another way, according to Yousef et. al (2017), organizational commitment consists of three main categories. The first type is affective commitment relates mainly to emotional attachment, identification with and involvement in. The second one is continuance commitment which is based on the leaving organizational costs. Normative commitment is the third type known as a sense of obligation to the organization (Yousef, 2017). In fact, organizational commitment has been defined and conducted in a variety of research perspectives and methods. For contributing more empirical results, the purpose of this paper aims to propose a model of antecedents strengthening organizational commitment in the context of Vietnamese organizations in order to help leaders making plans of action or designing suitable and efficient policies for motivating employees to increase their job performance and have more commitment to their organization. The result is collected by the survey of two hundred and forty-nine fulltime Vietnamese employees who are working at about 34 Vietnamese organizations from a variety of sectors such as tax, banking, health service, airlines, education and business. To begin with, the paper reviews six main concepts including organizational commitment, intrinsic motivation, extrinsic motivation, employee voice, organizational identification and perceived organizational support. Next, Five-point Likert scale is used to measure those factors with two hundred and forty-nine fulltime * Corresponding author.

E-mail address: nhutynguyen@gmail.com nhutynguyen@hcmiu.edu.vn (N.T. Nguyen) 
Vietnamese employees who are working at 34 Vietnamese organizations from a variety of sectors such as tax, banking, health service, airlines, education and business. Finally, quantitative research is obtained by using EFA, CFA analysis and Structural equation modeling. The findings show that four prominent factors positively affecting organizational commitment are intrinsic motivation, extrinsic motivation, employee voice and organizational identification.

\section{Literature review}

\subsection{Organizational commitment}

Previously, there was an ambiguity in the concepts of organizational commitment and organizational identification. In recent years, these terms have been discussed theoretically and tested empirically by Gautam et.al (2004). These authors strongly conclude that whereas organizational identification is self-referential or self-definitional, commitment is not and that while identification is related to perceived similarity and shared fate with the organization, commitment is formed by exchangebased factors known as the relationship between the individual and the organization (Gautam, Dick, \& Wagner, 2004). Employees feel more attachment to the organizational goals and values toward organizational commitment (Buchanan, 1974; Cook \& Wall, 1980). As reviewed by Mowday et al. (1978), the concept of organizational commitment is defined as from the two main perspectives: behaviors and attitude. It is the relation between an individual's identification and involvement with the organization in which people work for. Moreover, organizational commitment can be symbolized by at least there elements "1) a strong belief in arid acceptance of the organization's goals and values; 2) a willingness to exert considerable effort on behalf of the organization; and 3) a strong desire to maintain membership in the organization" (Mowday et al., 1978; Steers, 1977) and is a process of identification (Reichers, 1985). From recent researches, according to Yousef et al. (2017), organizational commitment is originated from 3 distinct categories. The first type is affective commitment relates mainly to emotional attachment, identification with and involvement in. The second one is continuance commitment which is based on the leaving organizational costs. Normative commitment is the third type known as a sense of obligation to the organization (Yousef, 2017).

\subsection{Organizational Identification}

It's quite different from organizational commitment. Organizational identification is self-definitional or self-referential (Gautam, Dick, \& Wagner, 2004). The first term that needs to be explained is identification. It is the role's defining essence defined by an individual (Ashforth, Harrison, \& Corley, 2008). From his study, Gautam (2004) finds out that organizational identification refers to the individuals' definition of him or herself (Gautam et al., 2004) and is defined as the perception of oneness or belongingness with an organization where he or she tightly involves in and shares with its successes and failures (Mael \& Ashforth, 1992). To some extent, the concept of identification is related to three dimensions: oneness, loyalty and shared characteristics. While oneness is the share of common goals with others in an organization, loyalty is shown in terms of attitudes and behaviors protecting the organization. Shared characteristics are what individuals and others in the organization have in common (Lee, 1970). Put it another way, organizational identification is the part of more general definition as identification with a psychological group which is perceptual rather than affective (Albert, Ashforth, \& Dutton, 2000; Mael \& Ashforth, 1992) and it stays when an individual feels proud of being a part of a group and highly appreciates the group's values and achievements without gaining them as his or her possession (Charles O'Reilly \& Chatman, 1986). Importantly, organizational identification has been criticized to help strengthen a sense of meaning, belonging and control at the workplace (Kreiner \& Ashforth, 2004).So far forth as Knippenberg's conclusion, the fundamental difference between identification and commitment originated from the relationship between individual and organization is that whereas identification relates to psychological oneness, commitment shows a bond between separate psychological entities (Edwards, 2005; Knippenberg \& Sleebos, 2006). Therefore, the authors posit:

\section{$\mathrm{H}_{1}$ : Organizational identification will positively affect Organizational commitment.}

Besides this, motivation also plays an essential role in forming employees' commitment with an organization.

\subsection{Internal and External Motivation}

There have been some previous studies on motivation and its relationship with organizational commitment (M..J. Moon, 2000). Motivation term is commonly defined as a sense of achievement, recognition for high performance, responsibility and individual development and considered as a psychological process of the exchange between individual and environment (Jones \& Lloyd, 2005; Latham \& Pinder, 2005). Two main drivers of motivation are intrinsic and extrinsic (Gagne et al., 2010; Kuvass, Buch, Weibel, Dysvik, \& Nerstad, 2017; Moon, 2000). Whereas the former relates to the state of interest and enjoy, the latter is about doing something for instrumental reasons (Gagne et al., 2010; Katzell \& Thompson, 1990). In other words, while intrinsic motivation is linked to work engagement, positive outcomes, productivity, extrinsic one is built by visible incentives (Kuvass et al., 2017). From another perspective known as Self-Determination theory, Garne (2015) reveals a multidimensional definition of motivation that consists of the two main forms: autonomous and controlled motivation. The author prefers autonomous, because while autonomous motivation is about individuals' optimal functioning such as wellbeing, performance etc., controlled one is less beneficial (Gagne, Forest, \& Vansteenkiste, 2015). However, above all, most researchers believe that the role of stimulating employees to raise their voice doesn't really relate to money and recognition. 
Those who have a sense of achievement or job importance are likely to have more commitment to an organization. That's the reason for most authors to confirm that intrinsic drivers dominate extrinsic rewards (Jones \& Lloyd, 2005; Kuvass et al., 2017; Moon, 2000; Tremblay, Blanchard, Taylor, Pelletier, \& Villeneuve, 2009). This leads to the following hypotheses:

\section{$\mathrm{H}_{2}$ : Intrinsic motivation will positively affect Organizational commitment.}

$\mathrm{H}_{3}$ : Extrinsic motivation will positively affect Organizational commitment.

Motivation cannot be existed without receiving supports from the organization. Perceived organizational support is supposed as the leverage for stronger organizational commitment.

\subsection{Perceived Organizational Support}

Perceived organizational support (POS) is considered as the antecedent increasing employee's attachment to the organization (Eisenberger \& Huntington, 1986; Shore \& Wayne, 1993). It results from organization's treatment to an employee in a wide variety of situations such as illnesses, mistakes, performance and so forth in order to make employee's job interesting and useful and meets the needs for praise and approval (Eisenberger \& Huntington, 1986). Moreover, POS is considered as employees' perceptions of the organization's commitment which are relied on how the organization recognizes their contributions and support their well-being (Kim, Eisenberger, \& Baik, 2016; Shore \& Wayne, 1993). Having the same perspective, Eisenberger et. al believe that POS relates to meeting employees' socio-emotional needs and the readiness the organization does to appreciate increased work endeavor (Eisenberger et al., 2002). This term becomes more interesting for recent studies because it positively affects job satisfaction and organizational commitment (Jaiswal \& Dhar, 2016). POS will be stronger in case the organization assures to make an employee's job effective and decrease stressful situations (Rhoades \& Eisenberger, 2002). The prominent beneficial influence of POS is that it creates among employees a feeling of obligation to repay the positive treatment they received from their organization (Caesens et al., 2015; Eisenberger et al., 1990). Thus:

$\mathrm{H}_{4}$ : Perceived organizational support will positively affect Organizational commitment.

Moreover, in order to partly contribute to the organizational outcome, employee voice also plays an important role.

\subsection{Voice}

In the organizational science, the term voice has been defined in various ways. Farndale (2011) states that voice relates to employees' ability to affect the outcome of organizational decisions by giving them the chance to raise their ideas (Farndale, Rruiten, clare Kelliher, \& Hailey, 2011). Traditionally, it is defined mostly as criticism of one's work organization but recently voice is defined as offering improvements, discussing problems in the workplace (Cosier, Dalton, \& Taylor, 1991). In terms of employee voice, it is originated by several purposes such as rectifying a problem with management, offering a countervailing source of control to management, contributing to improve quality and outcomes, or suggesting long-term viability for organization(Tony, Adrian, Mick, \& Peter, 2004). In addition, based on Dyne's study, voice consists of two elements: employees' complaints or grievance at work to management and employees' participation in decision-making processes of the organization and is divided into two types: mandated voice and voluntary voice (Linn Van Dyne, Ang, \& Botero, 2003). Similarly, Detert (2007) claims that voluntary voice considered as upward voice is preferred by communicating suggestions, information or strategies to management (Detert \& Burris, 2007; Morrison, 2014). Levels of employee engagement are either directly or indirectly influenced by employee perceptions of voice behavior targeting at increasing job performance (Rees, Alfes, \& Gatenby, 2013a). As the result, the authors propose:

\section{$\mathrm{H}_{5}$ : Voice will positively affect Organizational commitment.}

\section{Method and results}

\subsection{Data Collection}

The data for research is based on the survey of two hundred and forty-nine fulltime Vietnamese employees who are working at 34 Vietnamese organizations from a variety of sectors such as tax, banking, health service, airlines, education and business. All correspondents are subordinates with various titles from middle managers to staffs. The questionnaire was contained six constructs including organizational commitment, intrinsic motivation, extrinsic motivation, employee voice, organizational identification and perceived organizational support and distributed as hard copies that required handwritten responses. Fivepoint Likert scale is used to measure those factors with 32 items: totally disagree, disagree, neutral, agree, totally agree. A total of 280handouts of the questionnaire were delivered within six months in Hochiminh City and other neighboring provinces in southern Vietnam. However, only 249 handouts were returned and valid. Quantitative research is conducted by nonprobability sampling and obtained by using EFA, CFA analysis and Structural Equation Modeling.

\subsection{Data analysis and Results}

To ensure the items in the questionnaire to be valid and reliable, the questionnaire is surveyed by two hundred and forty nine participants. The descriptive statistics result shows that it ranges with mean from 3.41 to. 4.0 and its standard deviations fluctuate from 0.756 to 0.976 . Moreover, Cronbach's Alpha ratio is 0.966 (>0.8) with 32 items (see Table 1). 
Table 1

Descriptive statistics

\begin{tabular}{|c|c|c|c|c|c|}
\hline & $\mathrm{N}$ & $\min$ & $\max$ & Mean & Std. Dev. \\
\hline OGC1.You have warm feelings toward this organization as a place to live and work. & 249 & 1 & 5 & 3.74 & .856 \\
\hline OGC2.You feel yourself to be part of the organization. & 249 & 1 & 5 & 3.68 & .857 \\
\hline OGC3.You like to feel you are making some effort, not just for yourself but for the organization as well. & 249 & 1 & 5 & 3.90 & .792 \\
\hline OGC4.You really feel as if this organization's problems are your problems. & 249 & 1 & 5 & 3.96 & .756 \\
\hline OGC5.You feel a sense of pride working for this organization. & 249 & 1 & 5 & 3.85 & .804 \\
\hline OGC6.In your work, you are willing to put in a great deal of effort beyond that normally expected. & 249 & 1 & 5 & 3.82 & .778 \\
\hline $\begin{array}{l}\text { OGC7. The offer of a bit more money with another employer would not seriously make you think of changing } \\
\text { your job. }\end{array}$ & 249 & 1 & 5 & 3.41 & .976 \\
\hline EV2.Subordinates strongly express ideas. & 249 & 1 & 5 & 3.73 & .784 \\
\hline EV3.Leaders here at listening ideas and suggestions from subordinates. & 249 & 1 & 5 & 3.96 & .805 \\
\hline EV4.Leaders here at responding to suggestions from employees. & 249 & 1 & 5 & 4.00 & .854 \\
\hline IM01.Doing your job well gives you the feeling that you have accomplished something worthwhile. & 249 & 1 & 5 & 3.96 & .750 \\
\hline IM02.The things you do on your job are important to you. & 249 & 1 & 5 & 3.93 & .762 \\
\hline IM03.You enjoy this work very much. & 249 & 1 & 5 & 3.87 & .769 \\
\hline IM04.You have fun doing your job. & 249 & 1 & 5 & 3.82 & .797 \\
\hline EM01.If you produce a high quality of work output, you will lead to higher pay. & 249 & 1 & 5 & 3.73 & .909 \\
\hline EM03.It allows you to make a lot of money. & 249 & 1 & 5 & 3.28 & .976 \\
\hline EM04.Producing a low quality of work decreases your chances for promotion. & 249 & 1 & 5 & 3.71 & .911 \\
\hline POS1.The organization is willing to extend itself in order to help you perform your job to the best of my ability. & 249 & 1 & 5 & 3.79 & .770 \\
\hline POS2.Help is available from the organization when you have a problem. & 249 & 1 & 5 & 3.75 & .791 \\
\hline POS3. The organization wishes to give you the best possible job for which you are qualified. & 249 & 1 & 5 & 3.77 & .813 \\
\hline POS4.The organization is willing to help you when you need a special favor. & 249 & 1 & 5 & 3.78 & .775 \\
\hline POS5.The organization would understand if you were unable to finish a task on time. & 249 & 1 & 5 & 3.45 & .879 \\
\hline POS6. The organization really cares about my well-being. & 249 & 1 & 5 & 3.49 & .907 \\
\hline OI01.You are proud to be an employee of the organization. & 249 & 1 & 5 & 3.81 & .737 \\
\hline $\begin{array}{l}\text { OI02.You often describe yourself to others by saying 'I work for this organization' or 'I am from this organiza- } \\
\text { tion.' }\end{array}$ & 249 & 1 & 5 & 3.84 & .812 \\
\hline OI03.You talk up this organization to your friends as a great company to work for. & 249 & 1 & 5 & 3.60 & .888 \\
\hline OI04.You become irritated when you hear others outside the organization criticize your organization & 249 & 1 & 5 & 3.62 & .922 \\
\hline OI05.You have warm feelings toward this organization as a place to work. & 249 & 1 & 5 & 3.82 & .833 \\
\hline $\begin{array}{l}\text { OI06. You would describe your organization as a large 'family' in which most members feel a sense of belong- } \\
\text { ing. }\end{array}$ & 249 & 1 & 5 & 3.71 & .905 \\
\hline $\begin{array}{l}\text { OI07.You are willing to put in a great deal of effort beyond that normally expected to help this organization to } \\
\text { be successful. }\end{array}$ & 249 & 1 & 5 & 3.99 & .868 \\
\hline
\end{tabular}

EFA factor analysis is the next step. It is analyzed in two phases. Phase one is for independent variables, and phase two is for the dependent one. In the first phase, five independent variables which are intrinsic motivation, extrinsic motivation, employee voice, organizational identification and perceived organizational support are included in EFA factor analysis with principal components method and rotation Varimax. Specifically, KMO equals to $0.931(\geq 0.5)$ and sig.001 $(\leq 0.05)$, therefore Bartlett's Test is statistically significant (see Table 2).

Table 2

KMO and Bartlett's Test

Kaiser-Meyer-Olkin Measure of Sampling Adequacy. Bartlett's Test of Sphericity

\begin{tabular}{lr} 
& .931 \\
Approx. Chi-Square & 4583.813 \\
df & 300 \\
Sig. & .000 \\
\hline
\end{tabular}

After Rotation method Varimax with Kaiser Normalization, 25 items of independent variables are separated into four factors. Component 1 consists of eight items, however one item IM03 is eliminated because the difference of factor loadings between two factors is less than 0.3 . Thus, component 1 contains seven items named Organizational identification: IO1, IO2, IO3, IO4, IO5, IO6, IO7. Component 2 involves eight items called Employee voice: POS1, POS2, POS3, POS4, EV1, EV2, EV3, EV4. However, POS2 and POS4 are eliminated because the difference of factor loadings between two factors is less than 0.3 . Similarly, component 3 mainly includes four items grouped as Extrinsic motivation: EM2, EM3, POS5, POS6 while POS2 and POS4 are removed. Last but not least, Intrinsic motivation is for component 4, mainly containing 5 items: IM01, IM02, IM04, EM01, EM04. The rest of component 4, item IM03 is dropped because the difference of factor loadings between two factors is less than 0.3. The evaluation of Cronbach's Alpha after EFA analysis rotatedfor4 factors: Organizational identification, Employee voice, Extrinsic motivation and Intrinsic motivation are simultaneously equal to $.922, .887, .840$ and .825 with KMO of $0.912,0.866,0.736$ and 0.794 , respectively. They all are accepted. (see Table 3 ). In the second phase, the dependent variable "organizational Commitment" is evaluated by EFA analysis. The result is that the evaluation of Cronbach's Alpha for dependent variable "Organizational Commitment" is .916 which is accepted. Furthermore, KMO equals to 0.931 ( $\geq 0.5$ ) and sig.001 $(\leq 0.05)$ that also mean the Bartlett's Test is statistically significant and all factor loadings are more than 0.505 . (see Table 4). 
Table 3

EFA Result - Rotated Component Matrix

\begin{tabular}{|c|c|c|c|c|}
\hline & \multicolumn{4}{|c|}{ Component } \\
\hline & 1 & 2 & 3 & 4 \\
\hline EV1 & & .740 & & \\
\hline EV2 & & .684 & & \\
\hline EV3 & & .773 & & \\
\hline EV4 & & .742 & & \\
\hline POS1 & & .505 & & \\
\hline POS2 & & .531 & .546 & \\
\hline POS3 & & .684 & & \\
\hline POS4 & & .610 & .555 & \\
\hline POS5 & & & .624 & \\
\hline POS6 & & & .583 & \\
\hline IM01 & & & & .594 \\
\hline IM02 & & & & .674 \\
\hline IM03 & .522 & & & .503 \\
\hline IM04 & & & & .560 \\
\hline EM01 & & & & .549 \\
\hline EM02 & & & .742 & \\
\hline EM03 & & & .850 & \\
\hline EM04 & & & & .571 \\
\hline OI01 & .735 & & & \\
\hline OI02 & .642 & & & \\
\hline OI03 & .768 & & & \\
\hline OI04 & .693 & & & \\
\hline OI05 & .798 & & & \\
\hline OI06 & .712 & & & \\
\hline OI07 & .638 & & & \\
\hline Eigenvalue & 4.790 & 3.839 & 2.704 & 2.949 \\
\hline Cumulative & 68.422 & 63.987 & 67.600 & 58.976 \\
\hline Cronbach Alpha & 0.922 & 0.887 & 0.840 & 0.825 \\
\hline
\end{tabular}

Table 4

KMO and Bartlett's Test

Kaiser-Meyer-Olkin Measure of Sampling Adequacy.

Bartlett's Test of Sphericity

\section{Approx. Chi-Square}

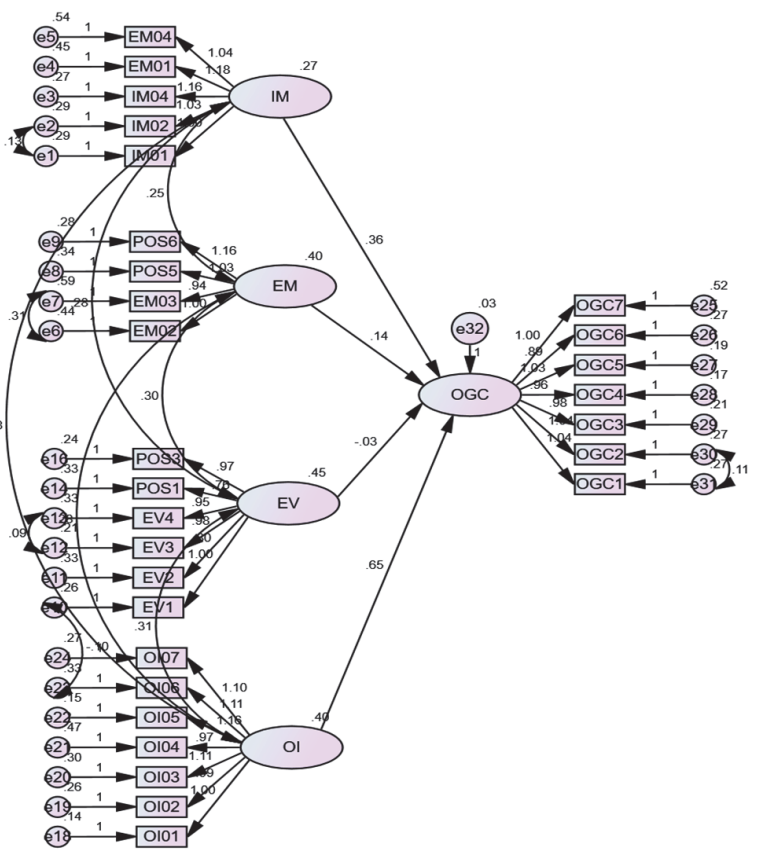

Fig. 1. Results of CFA concepts of research model (standardized) $\mathrm{P}=.000 ; \mathrm{CFI}=.884 ; \mathrm{TLI}=.870 ; \mathrm{GFI}=.781 ; \mathrm{RMSEA}=.084$.

\section{CFA Factor Analysis}


Table 6

$\underline{\text { Regression Weights }}$

\begin{tabular}{|c|c|c|c|c|c|c|c|}
\hline & & & Estimate & S.E. & C.R. & $\mathrm{P}$ & Label \\
\hline OGC & $\leftarrow$ & IM & .364 & .155 & 2.350 & .019 & \\
\hline OGC & $\leftarrow$ & EM & .138 & .067 & 2.051 & .040 & \\
\hline OGC & $\leftarrow$ & $\mathrm{EV}$ & -.034 & .071 & -.475 & .635 & \\
\hline OGC & $\leftarrow$ & OI & .649 & .099 & 6.584 & $* * *$ & \\
\hline IM01 & $\leftarrow$ & IM & 1.000 & & & & \\
\hline IM02 & $\leftarrow$ & IM & 1.033 & .077 & 13.443 & $* * *$ & \\
\hline IM04 & $\leftarrow$ & IM & 1.162 & .108 & 10.719 & $* * *$ & \\
\hline EM01 & $\leftarrow$ & IM & 1.178 & .122 & 9.631 & $* * *$ & \\
\hline EM04 & $\leftarrow$ & IM & 1.040 & .121 & 8.561 & $* * *$ & \\
\hline EM02 & $\leftarrow$ & EM & 1.000 & & & & \\
\hline EM03 & $\leftarrow$ & EM & .944 & .071 & 13.303 & $* * *$ & \\
\hline POS5 & $\leftarrow$ & EM & 1.033 & .103 & 10.018 & $* * *$ & \\
\hline POS6 & $\leftarrow$ & EM & 1.163 & .109 & 10.637 & $* * *$ & \\
\hline EV1 & $\leftarrow$ & $\mathrm{EV}$ & 1.000 & & & & \\
\hline EV2 & $\leftarrow$ & $\mathrm{EV}$ & .796 & .071 & 11.217 & $* * *$ & \\
\hline EV3 & $\leftarrow$ & EV & .981 & .070 & 14.045 & $* * *$ & \\
\hline EV4 & $\leftarrow$ & $\mathrm{EV}$ & .945 & .077 & 12.359 & $* * *$ & \\
\hline POS1 & $\leftarrow$ & $\mathrm{EV}$ & .758 & .070 & 10.815 & $* * *$ & \\
\hline POS3 & $\leftarrow$ & $\mathrm{EV}$ & .967 & .071 & 13.667 & $* * *$ & \\
\hline OI01 & $\leftarrow$ & OI & 1.000 & & & & \\
\hline OI02 & $\leftarrow$ & OI & .994 & .066 & 15.104 & $* * *$ & \\
\hline OI03 & $\leftarrow$ & OI & 1.105 & .071 & 15.525 & $* * *$ & \\
\hline OI04 & $\leftarrow$ & $\mathrm{OI}$ & .971 & .080 & 12.083 & $* * *$ & \\
\hline OI05 & $\leftarrow$ & $\mathrm{OI}$ & 1.164 & .061 & 19.072 & $* * *$ & \\
\hline OI06 & $\leftarrow$ & OI & 1.112 & .073 & 15.274 & $* * *$ & \\
\hline OI07 & $\leftarrow$ & OI & 1.101 & .069 & 16.019 & $* * *$ & \\
\hline OGC7 & $\leftarrow$ & OGC & 1.000 & & & & \\
\hline OGC6 & $\leftarrow$ & OGC & .887 & .082 & 10.832 & $* * *$ & \\
\hline OGC5 & $\leftarrow$ & OGC & 1.031 & .086 & 12.016 & $* * *$ & \\
\hline OGC4 & $\leftarrow$ & OGC & .960 & .081 & 11.912 & $* * *$ & \\
\hline OGC3 & $\leftarrow$ & OGC & .981 & .084 & 11.657 & $* * *$ & \\
\hline OGC2 & $\leftarrow$ & OGC & 1.038 & .091 & 11.420 & $* * *$ & \\
\hline OGC1 & $\leftarrow$ & OGC & 1.038 & .091 & 11.436 & $* * *$ & \\
\hline
\end{tabular}

The results of CFA factor analysis of the research model are presented in Fig. 1 . They are presented as follow: $\mathrm{P}=.000 ; \mathrm{CFI}=$ $.884 ; \mathrm{TLI}=.870 ; \mathrm{GFI}=.781 ; \mathrm{RMSEA}=.084$. According to the conditions with $\mathrm{P}<0.05 ; \mathrm{CFI}, \mathrm{TLI} \geq 0.8$; GFI is approximately equal to 0.781 and RMSEA is approximately equal to 0.08 and they both meet the requirements. Considering the above conditions, the model is consistent with market data. Based on the results in Table 6, the parameters (standardized) are statistically significant $(\mathrm{p}<0.05)$. However, three factors IM, EM and IO have significant effects on Organizational commitment with P-value $<0.05$, while EV with weight of -.034 and P-value 0.635 does not. According to the regression weight between factors shown, while intrinsic motivation positively affects organizational commitment with weight of .364, extrinsic motivation positively affects organizational commitment with weight of .138. Specifically, when intrinsic motivation goes up by 1 standard deviation, organizational commitment goes up by 0.364 standard deviation and when extrinsic motivation goes up by 1 standard deviation, organizational commitment goes up by 0.138 standard deviation. Similarly, with weight of .649, organizational identification has a positive effect on organizational commitment. Clearly, whenever organizational identification goes up by 1 standard deviation, organizational commitment goes up by 0.649 standard deviation. (see Table 6 ).

\section{Discussion}

It is found that empirically, three antecedents mainly affecting organizational commitment are intrinsic motivation, extrinsic motivation and organizational identification but not employee voice. It may be explained that whereas employee voice is mentioned in the literature of organizational commitment as the outcome of organizational decision, it is insignificant in statistics because if the voice is mandated but not voluntary, in the long run, it will diminish employee's working enthusiasm and contribution and decrease job performance (Rees, Alfes, \& Gatenby, 2013b). However, to those three main antecedent influencing organizational commitment, it is obvious that motivation plays an important role in encouraging employees to work much better for higher performance with a sense of achievement, and take more responsibility to their job (Jones \& Lloyd, 2005; Latham \& Pinder, 2005). Both intrinsic and extrinsic motivations really work well. Even though either of them has its own beneficial values, they are all linked to positive outcomes, higher productivity and even more organizational commitment. Employees tend to engage in their work and their organization (Gagne et al., 2010; Katzell \& Thompson, 1990; Kuvass et al., 2017). Apparently, when employees feel engaged, they naturally have the perception of identification. In other words, they have their loyalty and shared characteristics with their organization and its success or failure as well (Lee, 1970; 
Mael \& Ashforth, 1992).Furthermore, they also feel proud of being a part of an organization and highly recommend the organization's values and achievement (Charles O'Reilly \& Chatman, 1986).

\section{Implications and discussion}

\subsection{Implications}

For future research, in order to facilitate employees to more engage in their job and organization, based on the literature of organizational commitment, there are more factors which have the great impacts on organizational commitment rather than just these three ones. Therefore, what we should do next is to find out more factors affecting organizational commitment besides what have been investigated in this paper.

\section{Conclusion}

Recent years have witnessed a special interest in the concept of organizational commitment since it will bring several beneficial results to organizations. The term organizational commitment has been variably defined, measured, and researched. However, it has yet researched fully in the Vietnamese context. With the survey of 34 organizations from a variety of sectors such as tax, banking, health service, airlines, education and business, the findings show that empirically, three main antecedents that positively affect organizational commitment are intrinsic motivation, extrinsic motivation and organizational identification. The model of antecedents strengthening organizational commitment will help leaders making plans of action or designing suitable and efficient policies for motivating employees to increase their job performance and have more commitment to their organization.

\section{References}

Albert, S., Ashforth, B. E., \& Dutton, J. E. (2000). Organizational identity and identification: Charting new waters and building new brigdes. Academy of Management Journal, 25(1), 13-17.

Ashforth, B. E., Harrison, S. H., \& Corley, K. G. (2008). Identification in Organizations:An Examination of Four Fundamental Questions. Journal of Management, 34(3). doi:10.1177/0149206308316059

Buchanan, B. (1974). Building Organizational Commitment: The Socialization of Managers in Work Organizations Administrative Science Quarterly, 4, 533-546.

Caesens, G., Marique, G., Hanin, D., \& Stinglhamber, F. (2015). The relationship between perceived organizational support and proactive behaviour directed towards the organization. European Journal of Work and Organizational Psychology.

Charles O'Reilly, C., \& Chatman, J. (1986). Organizational Commitment and Psychological Attachment: The Effects of Compliance, Identification, and Internalization on Prosocial Behavior. Journal of Applied Psychology, 71(3), $492-499$.

Cook, J., \& Wall, T. (1980). New work attitude measures of trust, organizational commitment and personal need nonfulfilment. Journal of Occupational Psychology, 53, 39-52.

Cosier, R. A., Dalton, D. R., \& Taylor, L. A. (1991). Positive effects of cognitive conflict and employee voice. Employee Responsibilities and Rights Journal, 4(1).

Detert, J. R., \& Burris, E. R. (2007). Leadership behavior and employee voice-Is the door really open. Academy of Management Journal, 50(4), 869-884.

Edwards, M. R. (2005). Organizational identification: A conceptual and operational review. International Journal of Management Reviews, 7(4), 207-230

Eisenberger, R., Fasolo, P., \& LaMastro, V. D. (1990). Perceived organizational support and employee diligence, commitment, and innovation. Journal of Applied Psychology, 75(1), 51-59.

Eisenberger, R., \& Huntington, R. (1986). Perceived organizational support. Journal of Applied Psychology, 51(3).

Eisenberger, R., Stinglhamber, F., Vandenberghe, C., Sucharski, I. L., \& Rhoades, L. (2002). Perceived supervisor support: contributions to perceived organizational support and employee retention. Journal of Applied Psychology, 87(3), 565-573.

Farndale, E., Rruiten, J. V., clare Kelliher, C., \& Hailey, V. H. (2011). The inflluence of perceived employee voice on organizational commitment, an exchange perspective. Human Resource Management, 50(1), 113 - 129.

Gagne, M., Forest, J., M.H., M.-H. G., \& Aube, C. (2010). The motivation at work scale: Validation evidence in two languages. Educational and Psychological Measurement, 70(4), 628 -646

Gagne, M., Forest, J., \& Vansteenkiste, M. (2015). The multidimensional work motivation scale: Validation evidence in seven languages and nine countries. European Journal of Work and Organizational Psychology, 24(2), 178-196.

Gautam, T., Dick, R. V., \& Wagner, U. (2004a). Organizational identification and organizational commitment: Distinct aspects of two related concepts. Asian Journal of Social Psychology, 7, 301-315.

Jaiswal, D., \& Dhar, R. L. (2016). Impact of perceived organizational support, psychological empowerment and leader member exchange on commitment and its subsequent impact on service quality. International Journal of Productivity and Performance Management, 65(1), 58-79.

Jones, N. B., \& Lloyd, G. C. (2005). Does Herzberg's motivation theory have staying power?. Journal of Management Development, 24(10), 929-943

Katzell, R. A., \& Thompson, D. E. (1990). Work motivation theory and practice. American Psychologist, 45(2), $144-153$. 
Kim, K. Y., Eisenberger, R., \& Baik, K. (2016). Perceived organizational support and affective organizational commitment: Moderating influence of perceived organizational competence. Journal of Organizational Behavior, 37, $558-583$. doi:10.1002/job.2081

Knippenberg, D. V., \& Sleebos, A. E. (2006). Organizational identification versus organizational commitment: Self-definition, social exchange, and job attitudes. Journal of Organizational Behavior, 27(571-584

Kreiner, G. E., \& Ashforth, B. E. (2004). Evidence toward an expanded model of organizational identification. Journal of Organizational Behavior, 25, 1-27. doi:10.1002/job.234

Kuvass, B., Buch, R., Weibel, A., Dysvik, A., \& Nerstad, C. G. L. (2017). Do intrinsic and extrinsic motivation relate differently to employee outcomes? Journal of Economic Psychology, 61, 244-258.

Latham, G. P., \& Pinder, C. C. (2005). Work motivation theory and research at the dawn of the twenty-first century. Annual Review of Psychology, 56, 485-516.

Lee, S. M. (1970). An empirical analysis of organizational identification. Academy of Management Journal, 14(2), $213-226$.

Linn Van Dyne, L. V., Ang, S., \& Botero, I. C. (2003). Conceptualizing employee silence and employee voice as multitimensional constructs. Journal of Management Studies, 40(6).

Mael, F., \& Ashforth, B. E. (1992). Alumni and their alma mater: A partial test of the reformulated model of organizational identification. Journal of Organizational Behavior, 13, 103-123

Moon, M. J. (2000). Organizational commitment revisited in new public management: Motivation, organizational culture, sector, and managerial level. Public Performance \& Management Review, 24(2), 177-194.

Morrison, E. W. (2014). Employee voice and silence. The Annual Review of Organizational Psychology and Organizational Behavior, 1, 173-197.

Mowday, R. T., Steers, R. M., \& Porter, L. W. (1978). The measurement of organizational commitment: A progress report. Technical report.

Rees, C., Alfes, K., \& Gatenby, M. (2013a). Employee voice and engagement: connections and consequences. The International Journal of Human Resource Management, 24(14), 2780-2798, .

Rees, C., Alfes, K., \& Gatenby, M. (2013b). Employee voice and engagement: connections and consequences. The International Journal of Human Resource Management, 14, 2780-2798.

Reichers, A. E. (1985). A review and reconceptualization of organizational commitment. The Academy of Management Review, 10(3), 465-476.

Rhoades, L., \& Eisenberger, R. (2002). Perceived organizational support: A review of the literature. Journal of Applied Psychology, 87(4), 698-714.

Shore, L. M., \& Wayne, S. J. (1993). Commitment and employee behavior: Comparison of affective commitment and continuance commitment with perceived organizational support. Journal of Applied Psychology, 78(5), 774-780.

Steers, R. M. (1977). Antecedents and outcomes of organizational commitment Administrative Science Quarterly, 22(1), 4656

Tony, D., Adrian, W., Mick, M., \& Peter, A. (2004). The meanings and purpose of employee voice. International Journal of Human Resource Management, 15(6), 1150-1171.

Tremblay, M. A., Blanchard, C. M., Taylor, S., Pelletier, L. G., \& Villeneuve, M. (2009). Work extrinsic and intrinsic motivation scale: Its value for organizational psychology research. Canadian Journal of Behavioural Science, 4, $213-226$. doi:10.1037/a0015167

Yousef, D. A. (2017). Organizational commitment, job satisfaction and attitudes toward organizational change: A study in the local government International Journal of Public Administration, 40(1), 77-88.

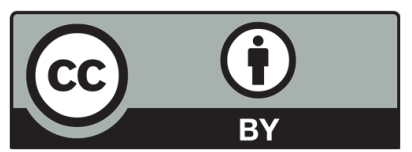

(C) 2021 by the authors; licensee Growing Science, Canada. This is an open access article distributed under the terms and conditions of the Creative Commons Attribution (CC-BY) license (http://creativecommons.org/licenses/by/4.0/). 